Available online at http://jddtonline.info

RESEARCH ARTICLE

\title{
INHIBITORY EFFECT OF LEAF AND BARK OF ANACARDIUM OCCIDENTALE AGAINST CLINICAL ISOLATES OF STAPHYLOCOCCUS AUREUS AND STREPTOCOCCUS MUTANS
}

\section{Chaithra M, Vivek MN, Asha M.M, Yashoda Kambar, Prashith Kekuda TR, Mallikarjun N*}

P.G. Department of Studies and Research in Microbiology, Sahyadri Science College campus, Kuvempu University, Shivamogga-577203, Karnataka, India

*Corresponding Author: Dr. N. Mallikarjun, Associate Professor and Chairman, P.G. Department of Studies and Research in Microbiology, Sahyadri Science College campus, Kuvempu University, Shivamogga, Karnataka-577203, India

Email: dr.mallikarjun2010@rediffmail.com

\begin{abstract}
The present study was undertaken to determine inhibitory activity of methanolic extract of leaf and bark of Anacardium occidentale L. (Anacardiaceae) against clinical isolates of Staphylococcus aureus and Streptococcus mutans recovered previously from burn and dental caries patients respectively. Agar well diffusion method was employed to investigate antibacterial activity. The extracts were found to be effective in inhibiting all clinical isolates. Leaf extract was found to inhibit bacteria to higher extent than bark extract. The inhibition of clinical isolates by the extracts could be ascribed to the presence of bioactive components present in the extracts.

Key words: Anacardium occidentale, Agar well diffusion, Burn, Dental Caries, Staphylococcus aureus, Streptococcus mutans
\end{abstract}

\section{INTRODUCTION}

Cashew (Anacardium occidentale L., Anacardiaceae) is a native to Brazil and is one of the most important plantation crops in countries such as India, Brazil, Nigeria and Vietnam. It is largely grown for the nuts (true fruit) having an exclusive fine taste and a commercial importance. The edible cashew apple (the thick receptacle or 'false fruit' to which the cashew nut or true fruit is attached) has high nutritive values and has found several applications in food industries and in breweries ${ }^{\mathbf{1 , 2 , 3}}$. Various parts such as leaf, pseudo-fruit, stem, nut shell, gum of the plant $A$. occidentale have been shown to possess several biological activities such as antimutagenic, anti-inflammatory, $\mathbf{5}^{\mathbf{4}, \mathbf{6}}$, analgesic $^{5,6}$ hypoglycemic ${ }^{7,8}$, antimicrobial $^{\mathbf{9 - 1 2}}$, antioxidant $^{13}$, antidiabetic ${ }^{14}$, renal protective ${ }^{8}$, aphrodisiac $^{15}$, insecticidal ${ }^{9}, \quad$ antiulcerogenic $^{16}$, hypocholesterolemic $^{17}, \quad \beta$-Lactamase inhibitory ${ }^{18}$ and acetylcholinesterase inhibitory activity ${ }^{\mathbf{1 9}}$. In the present study, we report antibacterial activity of methanolic extract of leaf and bark of A. occidentale against clinical isolates of Staphylococcus aureus and Streptococcus mutans isolated previously from burn and dental caries patients respectively.

\section{MATERIALS AND METHODS}

\section{Collection and identification of plant material}

Leaves and barks of $A$. occidentale were collected at Maragalale, Thirthahalli (taluk), Shivamogga (district), Karnataka during June 2013. The plant materials were washed thoroughly, shade dried and powdered in a blender. The powdered leaf bark materials were stored in air-tight containers.

\section{Extraction}

About $10 \mathrm{~g}$ of dried and powdered leaf and bark of $A$. occidentale were added to $100 \mathrm{ml}$ of methanol (HiMedia, Mumbai), sonicated for 30 minutes and left at room temperature overnight. The extracts were filtered through Whatman No. 1 filter paper, concentrated in vacuum under reduced pressure and dried in the desiccator ${ }^{20}$.

\section{Antibacterial activity of leaf and bark extracts}

Agar well diffusion assay was carried out to determine antibacterial activity of leaf extract (LE) and bark extract (BE) against five isolates of $S$. aureus (recovered previously from burn patients) and five isolates $S$. mutans (isolated from dental caries subjects previously). The isolates of $S$. aureus and $S$. mutans were grown in sterile Nutrient broth (HiMedia, Mumbai) and sterile Brain heart infusion broth (HiMedia, Mumbai) respectively for 24 hours at $37^{\circ} \mathrm{C}$. The broth cultures of $S$. aureus and $S$. mutans were aseptically swabbed on sterile Nutrient agar (HiMedia, Mumbai) and sterile Brain heart infusion agar (HiMedia, Mumbai) plates respectively using sterile cotton swabs. Wells of $6 \mathrm{~mm}$ diameter were made in the inoculated plates using sterile cork borer. 100 $\mu$ l of LE and $\mathrm{BE}(25 \mathrm{mg} / \mathrm{ml}$ of $25 \%$ dimethyl sulfoxide [DMSO]), standard antibiotic (Chloramphenicol, $1 \mathrm{mg} / \mathrm{ml}$ of sterile distilled water) and DMSO (25\%, in sterile water) were filled into labeled wells. The plates were incubated at $37^{\circ} \mathrm{C}$ for 24 hours and the zone of inhibition was measured using a ruler ${ }^{21}$.

\section{Statistical analysis}

The results are represented as Mean \pm Standard deviation $(n=3)$.

\section{RESULTS AND DISCUSSION}

Table 1 shows the inhibitory activity of LE and BE of $A$. occidentale against clinical isolates of $S$. aureus. Among extracts, LE was more effective (zone of inhibition ranging 1.5 to $1.8 \mathrm{~cm}$ ) in inhibiting bacterial isolates when compared to $\mathrm{BE}$ (zone of inhibition ranging 1.2 to $1.6 \mathrm{~cm}$ ). 
Chloramphenicol showed higher inhibition of bacteria than LE and BE. DMSO did not cause inhibition of bacteria (not shown in table).

Table 1: Inhibitory activity of LE and BE of $\boldsymbol{A}$. occidentale against $S$. aureus isolates

\begin{tabular}{|c|c|c|c|}
\hline \multirow{2}{*}{$\begin{array}{c}\text { Test } \\
\text { Bacteria }\end{array}$} & \multicolumn{3}{|c|}{ Zone of inhibition in cm } \\
\cline { 2 - 4 } & Solvent extract & \multirow{2}{*}{ Standard } \\
\cline { 2 - 3 } & LE & BE & \\
\hline Sa-01 & $1.8 \pm 0.2$ & $1.6 \pm 0.2$ & $3.1 \pm 0.5$ \\
\hline Sa-02 & $1.5 \pm 0.1$ & $1.2 \pm 0.1$ & $2.7 \pm 0.3$ \\
\hline Sa-03 & $1.7 \pm 0.2$ & $1.2 \pm 0.2$ & $2.4 \pm 0.1$ \\
\hline Sa-04 & $1.5 \pm 0.2$ & $1.2 \pm 0.1$ & $3.3 \pm 0.2$ \\
\hline Sa-05 & $1.5 \pm 0.2$ & $1.2 \pm 0.1$ & $3.2 \pm 0.2$ \\
\hline
\end{tabular}

Table 2 shows the antibacterial effect of LE and BE of $A$. occidentale against clinical isolates of $S$. mutans. Here also, among extracts, LE was more effective (zone of inhibition ranging 1.5 to $2.2 \mathrm{~cm}$ ) in inhibiting bacterial isolates when compared to $\mathrm{BE}$ (zone of inhibition ranging 1.3 to $1.5 \mathrm{~cm}$ ). Chloramphenicol caused higher inhibition of bacteria than LE and BE. DMSO did not cause inhibition of bacteria (not shown in table).

Table 2: Inhibitory activity of LE and BE of $\boldsymbol{A}$. occidentale against $S$. mutans isolates

\begin{tabular}{|c|c|c|c|}
\hline \multirow{2}{*}{$\begin{array}{c}\text { Test } \\
\text { Bacteria }\end{array}$} & \multicolumn{3}{|c|}{ Zone of inhibition in cm } \\
\cline { 2 - 4 } & Solvent extract & \multirow{2}{*}{ Standard } \\
\cline { 2 - 4 } & LE & BE & \\
\hline Sm-01 & $1.6 \pm 0.2$ & $1.3 \pm 0.1$ & $3.5 \pm 0.2$ \\
\hline $\mathrm{Sm}-02$ & $1.9 \pm 0.2$ & $1.4 \pm 0.2$ & $3.3 \pm 0.3$ \\
\hline $\mathrm{Sm}-03$ & $1.7 \pm 0.1$ & $1.3 \pm 0.1$ & $2.9 \pm 0.2$ \\
\hline $\mathrm{Sm}-04$ & $1.5 \pm 0.1$ & $1.5 \pm 0.1$ & $3.6 \pm 0.3$ \\
\hline $\mathrm{Sm}-05$ & $2.2 \pm 0.2$ & $1.4 \pm 0.1$ & $3.1 \pm 0.1$ \\
\hline
\end{tabular}

\section{DISCUSSION}

Burn wounds are more vulnerable and suitable sites for multiplication of pathogenic bacteria. These wounds are ideal sources of infection than surgical wounds because of the larger area involved and longer duration of patient stay in the hospital. The major cause of morbidity and mortality in hospitalized burn patients is infection caused by a number of pathogenic microbes. It is estimated that more than $75 \%$ of deaths following burn is related to infections. The bacteriology of burn wounds is usually poly-microbial in nature. The most common bacterial pathogens isolated from burn wounds are Staphylococcus aureus, Pseudomonas aeruginosa, Streptococcus pyogenes and various coilform bacilli. Among these, Staphylococcus aureus is frequently isolated in both community and hospital practices. S. aureus is one of the greatest causes of nosocomial infection in burn patients. The pattern of antimicrobial susceptibility of $S$. aureus is changing and therefore antimicrobial agents are becoming ineffective. Majority of strains of $S$. aureus in community as well as hospitals have developed resistance to commonly used antibiotics such as penicillin, methicillin and vancomycin. Infection of burn wounds caused by multidrug resistant pathogens is a serious threat for successful treatment ${ }^{22-27}$. It has been found that plants and their components are effective against $S$. aureus isolates

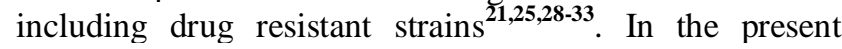
study, the extracts of $A$. occidentale were shown to be potent in causing inhibition of isolates of $S$. aureus recovered previously from burn patients.

Dental infections namely dental caries and periodontal diseases are among the most common human diseases. The ubiquitousness and non-life threatening nature have minimized their significance in overall health of humans. Mutans streptococci are found in highest numbers on teeth. Mutans streptococci are the streptococci found in plaque, ferment mannitol and sorbitol, produce extracellular glucans from sucrose and are cariogenic. Streptococcus mutans is often considered as the most important and primary aetiological agent among mutans streptococci responsible for causing dental caries in humans. S. mutans possesses the property to adhere to pellicle-coated tooth surfaces and to form acids ${ }^{34-40}$. Prevention and treatment of dental caries involves the use of antimicrobial mouth rinses such as triclosan and chlorhexidine and antibiotics such as penicillin, erythromycin, and ampicillin. However, the antimicrobial mouth rinses are reported to cause some undesirable side effects such as tooth staining, taste alteration and development of hypersensitivity reactions whereas antibiotics suffer from the major drawback that oral microflora are getting resistance against them ${ }^{\mathbf{3 3 , 3 7 , 4 1 , 4 2}}$. This has triggered interest in searching alternatives for treatment of dental caries. Plants have shown to be effective in the treatment of dental caries and a number of studies have shown the potential of plants and their metabolites to inhibit cariogenic flora ${ }^{21,33,39,42-49}$. In our study, leaf and bark extracts of $A$. occidentale displayed inhibition of $S$. mutans isolates recovered from dental caries subjects.

\section{CONCLUSION}

The extracts from leaf and bark $A$. occidentale displayed inhibition of clinical isolates of $S$. aureus and $S$. mutans. The inhibitory effect could be ascribed to the presence of bioactive components present in extracts. The plant can be employed as a potential candidate for the development of inhibitory agents active against clinical isolates.

\section{ACKNOWLEDGEMENTS}

Authors are thankful to Principal, Sahyadri Science College (Autonomous) for providing all facilities and moral support to conduct work. 


\section{REFERENCES}

1. Mohanty S, Ray P, Swain MR, Ray RC, Fermentation of cashew (Anacardium occidentale L.) "apple" into wine, Journal of Food Processing and Preservation, 2006, 30, 314-322.

2. Lowor ST, Agyente-Badu CK, Mineral and proximate composition of cashew apple (Anarcadium occidentale L.) juice from Northern Savannah, forest and Coastal Savannah regions in Ghana, American Journal of Food Technology, 2009, 4(4), 154161.

3. Marc A, Achille TF, Mory G, Koffi NPV, Georges AM, Minerals composition of the cashew apple juice (Anacardium occidentale L.) of Yamoussoukro, Cote D'ivoire, Pakistan Journal of Nutrition, 2011, 10(12), 1109-1114.

4. Melo-Cavalcante AA, Picada JN, Rubensam G, Henriques JAP, Antimutagenic activity of cashew apple (Anacardium occidentale Sapindales, Anacardiaceae) fresh juice and processed juice (cajuína) against methyl methanesulfonate, 4-nitroquinoline $\mathrm{N}$ oxide and benzo[a]pyrene, Genetics and Molecular Biology, 2008, 31(3), 759-766.

5. Pawar SP, Sathwane PN, Metkar BR, Pal SC, Kasture VS, Kasture SB, Anti-inflammatory and analgesic activity of Anacardium occidentale leaf extracts, Ancient Science of Life, 2000, 19(3-4), 169-173.

6. Vanderlinde FA, Landim HF, Costa EA, Galdino PM, Maciel MAM, dos Anjos GC, Malvar DC, Cortes WS, da Rocha FF, Evaluation of the antinociceptive and anti-inflammatory effects of the acetone extract from Anacardium occidentale L, Brazilian Journal of Pharmaceutical Sciences, 2009, 45(3), 437-442.

7. Ojewole JA, Laboratory evaluation of the hypoglycemic effect of Anacardium occidentale Linn (Anacardiaceae) stem-bark extracts in rats, Methods and Findings in Experimental and Clinical Pharmacology, 2003, 25(3), 199-204.

8. Tedong L, Dimo T, Dzeufiet PDD, Asongalem AE, Sokeng DS, Callard P, Flejou J, Kamtchouing P, Antihyperglycemic and renal protective activities of Anacardium occidentale (Anacardiaceae) leaves in streptozotocin induced diabetic rats, African Journal of Traditional, Complementary and Alternative Medicine, 2006, 3(1), 23-35.

9. Marques MR, Albuquerque LMB, Xavier-Filho J, Antimicrobial and insecticidal activities of cashew tree gum exudates, Annals of Applied Biology, 1992, 121(2), 371-377.

10. Kannan RV, Sumathi CS, Balasubramanian V, Ramesh N, Elementary chemical profiling and antifungal properties of cashew (Anacardium occidentale L.) nuts, Botany Research International, 2009, 2(4), 253-257.

11. Ayepola OO, Ishola RO, Evaluation of antimicrobial activity of Anacardium occidentale (Linn.), Advances in Medical and Dental Sciences, 2009, 3(1), 1-3.

12. Vivek MN, Manasa M, Pallavi S, Swamy SHC, Kekuda PTR, Antibacterial potential of Cashew apple (Anacardium occidentale L.) juice against clinical isolates of Staphylococcus aureus and Streptococcus mutans, Science Technology and Arts Research Journal, 2013, 2(3), 144-146.

13. Mokhtar NM, Kanthimathi MS, Aziz AA, Comparisons between the Antioxidant Activities of the Extracts of Anacardium occidentale and Piper betle, Malaysian Journal of Biochemistry and Molecular Biology, 2008, 16(1), 16-21.

14. Abdullahi S, Olatunji GA, Antidiabetic activity of Anacardium occidentale in alloxan-diabetic rats, Journal of Science and Technology, 2010, 30(3), 35-41.

15. Mbatchou VC, Kosoono I, Aphrodisiac activity of oils from Anacardium occidentale L. seeds and seed shells, Phytopharmacology, 2012, 2(1), 81-91,

16. Konan NA, Bacchi EM, Antiulcerogenic effect and acute toxicity of a hydroethanolic extract from the cashew (Anacardium occidentale L.) leaves, Journal of Ethnopharmacology, 2007, 112(2), 237-242.

17. Fazil MNF, Amom Z, Esa NM, Hasan MKN, Kadir KKA, Shah ZM, Arshad SM, Toxicity screening and hypocholesterolemic effect evaluation of aqueous extract of Anacardium occidentale Linn. in hypercholesterolemic induced rabbits, International Journal of Phytomedicine, 2011, 3(2), 192-197.

18. Bouttier S, Fourniat J, Garofalo C, Gleye C, Laurens A, Hocquemiller R, $\beta$-Lactamase inhibitors from Anacardium occidentale, Pharmaceutical Biology, 2002, 40(3), 231-234.

(C) 2011, JDDT. All Rights Reserved
19. De Lima SG, Feitosa CM, Cito AMGL, Neto MJM, Lopes JAD, Leite AS, Brito MC, Dantas SMM, Melo Cavalcante AAC, Effects of immature cashew nut-shell liquid (Anacardium occidentale) against oxidative damage in Saccharomyces cerevisiae and inhibition of acetylcholinesterase activity, Genetics and Molecular Research, 2008, 7(3), 806-818.

20. Vinayaka KS, Swarnalatha SP, Preethi HR, Surabhi KS, Kekuda PTR, Sudharshan SJ, Studies on in vitro antioxidant, antibacterial and insecticidal activity of methanolic extract of Abrus pulchellus Wall (Fabaceae), African Journal of Basic and Applied Sciences, 2009, 1(5-6), 110-116.

21. Kambar Y, Manasa M, Pallavi S, Vivek MN, Swamy SHC, Asha MM, Chaithra M, Kekuda PTR, Mesta SC, Onkarappa R, Mallikarjun N, Inhibitory efficacy of Caesalpinia pulcherrima, Delonix regia and Peltaphorum ferrugineum against clinical isolates of Staphylococcus aureus and Streptococcus mutans, Pharmanest, 2013, 4(5), 786-793.

22. Bagdonas R, Tamelis A, Rimdeika R, Staphylococcus aureus infection in the surgery of burns, Medicina, 2003, 39(11), 10781081.

23. Grigaite R, Pavilonis A, Rimdeika R, Antusevas A, Resistance of Staphylococcus aureus isolated from burn wounds to antibiotics, Medicina, 2006, 42(5), 377-383.

24. Naqvi ZA, Hashmi K, Kharal SA, Methicillin resistant Staphylococcus aureus (MRSA) in burn patients, Pakistan Journal of Pharmacology, 2007, 24(2), 7-11.

25. Alsaimary IE, Efficacy of some antibacterial agents on Staphylococcus aureus isolated from various burn cases, International Journal of Medicine and Medical Sciences, 2009, 1(4), 110-114.

26. Alebachew T, Yismaw G, Derabe A, Sisay Z, Staphylococcus aureus burn wound infection among patients attending Yekatit 12 hospital burn unit, Addis Ababa, Ethiopia, Ethiopian Journal of Health Sciences, 2012, 22(3), 209-213.

27. Bayram Y, Parlak M, Aypak C, Bayram I, Three-year review of bacteriological profile and antibiogram of burn wound isolates in Van, Turkey, International Journal of Medical Sciences, 2013, 10(1), 19-23.

28. Iinuma M, Tosa H, Tanaka T, Asai F, Kobayashi Y, Shimano R, Miyauchi K, Antibacterial activity of xanthones from guttiferaeous plants against methicillin-resistant Staphylococcus aureus, The Journal of Pharmacy and Pharmacology, 1996, 48(8), 861-865.

29. Palombo EA, Semple SJ, Antibacterial activity of Australian plant extracts against methicillin-resistant Staphylococcus aureus (MRSA) and vancomycin-resistant enterococci (VRE), Journal of Basic Microbiology, 2002, 42(6), 444-448.

30. Gibbons S, Leimkuge J, Oluwatuyi M, Heinrich M, Activity of Zanthoxylum clava-herculis extracts against multi-drug resistant methicillin-resistant Staphylococcus aureus (mdr-MRSA), Phytotherapy Research, 2003, 17(3), 274-275.

31. Aqil F, Khan MS, Owais M, Ahmad I, Effect of certain bioactive plant extracts on clinical isolates of beta-lactamase producing methicillin resistant Staphylococcus aureus, Journal of Basic Microbiology, 2005, 45(2), 106-114.

32. Mandal S, Mandal MD, Saha K, Pal NK, In vitro antibacterial activity of three Indian spices against methicillin-resistant Staphylococcus aureus, Oman Medical Journal, 2011, 26(5), 319323.

33. Asha MM, Chaithra M, Kambar Y, Vivek MN, Kekuda PTR, Antibacterial activity of leaf and bark extracts of Pimenta dioica (Linn.) Merill against clinical isolates of Staphylococcus aureus and Streptococcus mutans, World Journal of Pharmacy and Pharmaceutical Sciences, 2013, 2(5), 3207-3215.

34. Loesche WJ, Rowan J, Straffon LH, Loos PJ, Association of Streptococcus mutans with human dental decay, Infection and Immunity, 1975, 11(6), 1252-1260.

35. Hamada S, Koga T, Ooshima T, Virulence factors of Streptococcus mutans and dental caries prevention, Journal of Dental Research, 1984, 63(3), 407-411.

36. Loesche WJ, Role of Streptococcus mutans in human dental decay, Microbiology Reviews, 1986, 50(4), 353-380.

37. Jarvinen $\mathrm{H}$, Tenovuo J, Huovinen $\mathrm{P}$, In vitro susceptibility of Streptococcus mutans to chlorhexidine and six other 
antimicrobial agents, Antimicrobial Agents and Chemotherapy, 1993, 37(5), 1158-1159.

38. Durana I, Sengunb A, Hadimlic HH, Ulkerd M, Evaluation of antibacterial effectiveness of desensitizers against oral bacteria, European Journal of Dentistry, 2008, 2, 43-47.

39. Joycharat N, Limsuwan S, Subhadhirasakul S, Voravuthikunchai SP, Pratumwan S, Madahin I, Nuankaew W, Promsawat A, AntiStreptococcus mutans efficacy of Thai herbal formula used as a remedy for dental caries, Pharmaceutical Biology, 2012, 50(8), 941-947.

40. Goyal D, Sharma S, Mahmood A, Inhibition of dextransucrase activity in Streptococcus mutans by plant phenolics, Indian Journal of Biochemistry and Biophysics, 2013, 50(1), 48-53.

41. Sweeney LC, Dave J, Chambers PA and Heritage J, Antibiotic resistance in general dental practice-a cause for concern? Journal of Antimicrobial Chemotherapy, 2004, 53, 567-576.

42. Chaiya A, Saraya S, Chuakul W, Temsiririrkkul R, Screening for dental caries: Preventive activities of medicinal plants against Streptococcus mutans, Mahidol University Journal of Pharmaceutical Sciences, 2013, 40(1), 9-17.

43. Jose $\mathrm{S}$, Beegum GRJ, In vitro susceptibility of viridans streptococci to leaf extracts of Mangifera Indica, Indian Journal of Microbiology, 2007, 47, 160-163.
44. Yoo S, Murata RM, Duarte S, Antimicrobial traits of tea- and cranberry-derived polyphenols against Streptococcus mutans, Caries Research, 2011, 45, 327-335.

45. Venugopal TM, Swathi D, Suchitha Y, Prashith Kekuda TR, Mallikarjun N, Soundarya S, Eyasu Ejeta, Raghavendra HL, Mineral composition, cytotoxic and anticariogenic activity of Scleropyrum pentandrum (Dennst.) Mabb, International Journal of Drug Development and Research, 2011, 3(4), 344-350.

46. Swathi D, Suchitha Y, Venugopal TM, Kekuda PTR, Mallikarjun $\mathrm{N}$, Inhibitory efficacy of Croton gibsonianus Nimm. Grah (Euphorbiaceae) against oral isolates of Streptococcus mutans, International Journal of Pharmaceutical and Biological Archives, 2011, 2(3), 896-899.

47. Fani M, Kohanteb J, Inhibitory activity of Aloe vera gel on some clinically isolated cariogenic and periodontopathic bacteria, Journal of Oral Science, 2012, 54(1), 15-21.

48. Kekuda PTR, Raghavendra HL, Mallikarjun N, Venugopal TM, Kumar AHS, Elemental composition, anticariogenic, pancreatic lipase inhibitory and cytotoxic activity of Artocarpus lakoocha Roxb pericarp, International Journal of Drug Development and Research, 2012, 4(1), 330-336.

49. Junaid S, Dileep N, Rakesh KN, Kekuda PTR, Anticaries activity of selected plants against clinical isolates of Streptococcus mutans, Asian Journal of Pharmacy and Technology, 2013, 3(3), 105-106. 